\title{
Ultraviolet Radiation Sensitivity in Cave Bacteria: Evidence of Adaptation to the Subsurface?
}

\author{
Jessica R. Snider ${ }^{1}$, Caitlin Goin ${ }^{2}$, Robert V. Miller ${ }^{2}$, Penelope J. Boston ${ }^{3,4}$ and Diana E. Northup ${ }^{5}$
}

\begin{abstract}
:
Snider J.R., Goin C., Miller R.V., Boston P.J. and Northup D.E. 2009. Ultraviolet Radiation Sensitivity in Cave Bacteria: Evidence of Adaptation to the Subsurface? International Journal of Speleology, 38 (1), 13-22. Bologna (Italy). ISSN 0392-6672.

We hypothesize that a reduced capacity to withstand or repair cellular damage from ultraviolet radiation may be present in caveadapted microorganisms that never experience such conditions. However, a small number of previous studies have shown that some subsurface bacteria do not show greater sensitivity to ultraviolet radiation (UVR) than surface bacteria. To estimate UVR sensitivity in cave bacteria, bacterial isolates were collected from Carlsbad Cavern, New Mexico, U.S.A., and percent survival following exposure to various UVC and UVA radiation doses was determined. Cave bacteria from Left Hand Tunnel in Carlsbad Cavern and surface bacteria from soil and rocks above Carlsbad Cavern were grown on low and high nutrient media then exposed to 0, 10,000 and 20,000 $\mu \mathrm{Ws} /$ $\mathrm{cm}^{2}$ of UVR in a laboratory biological safety cabinet. Incubations were conducted at $15^{\circ} \mathrm{C}$ or $37^{\circ} \mathrm{C}$, in accordance with the isolates' natural temperature environments. In addition, DNA repair capacity was estimated by exposing the organisms to various doses of UVC radiation and measuring survivability. Gram status and pigmentation also were determined. Results showed that most of the cave isolates were more sensitive to UVR than the surface isolates, but survivability data suggest that cave microbes retain some of their capacity to repair UV-induced DNA damage. Selection appears to have favored bacteria that can survive in this low nutrient environment, while not maintaining (or paying the cost of maintaining) unneeded traits such as UVR resistance. Cave bacteria appear to have maintained DNA repair capacity, most likely because of the need to repair damage to their DNA from other environmental stressors found in caves.
\end{abstract}

Keywords: Ultraviolet radiation sensitivity, cave-adaptation, bacteria, subsurface, caves

Received 1 May 2008; Revised 7 September 2008; Accepted 10 September 2008

\section{INTRODUCTION}

Although much of life on Earth is directly or indirectly based on solar energy, radiation in the ultraviolet (UV) range is damaging to DNA and thus often lethal to organisms. Surface microorganisms have developed a number of mechanisms to protect themselves from the destructive effects of UV, probably very early in the history of the Earth (Walter 1983; Yasue \& McCready, 1998). However, in the dark zone of caves where there is constant, complete darkness, such UV protective adaptations may not be maintained. Jagger (1983) suggests that the amount of solar radiation present in an organism's environment dictates its level of UV resistance, while other researchers have been

1 Department of Biology, MSC03 2020, 1 University of New Mexico, Albuquerque, NM 87131,USA, snider@unm.edu 2 Department of Microbiology, Oklahoma State University, 307 Life Sciences East, Stillwater, OK 74078, USA, bob.miller@ okstate.edu

3 Earth and Environmental Science Department, New Mexico Institute of Mining and Technology, 801 Leroy Place, Socorro, NM 87801, USA, pboston@nmt.edu

4 National Cave and Karst Research Institute, 1400 Commerce

Dr. Carlsbad, NM 88220, USA, pboston@nmt.edu

5 Department of Biology, MSC03 2020, 1 University of New

Mexico, Albuquerque, NM 87131, USA, dnorthup@unm.edu unable to show a correlation between natural levels of radiation exposure and species resistance (Nasim \& James, 1978; Arrage et al., 1993a).

UV radiation (UVR) at wavelengths shorter than 400 $\mathrm{nm}$ is absorbed by DNA and can cause cyclobutane dimer formation, interstrand crosslinking, and other direct and indirect damage to DNA (Nasim \& James, 1978; Miller et al., 1999). In addition to enzymatic DNA repair mechanisms, microbes have evolved to survive UV exposure through other molecular and structural protection and avoidance methods. However, whether these additional methods actually protect the bacterial DNA is widely debated (Mathews \& Sistrom, 1959; Dworkin \& Stanley, 2006; Gascon et al., 1995; Lewis et al., 1973; Singer \& Ames, 1970; Nasium \& James, 1978; Cockell, 1998; Arrage et al., 1993a). Iron compounds, sand, desert crust, rock, water, sulfur and sodium chloride have all been found to be natural UVR shields for bacteria (Cockell, 1998; Rothschild \& Giver, 2003). A well-documented predominance of pigmentation in UVR-resistant species of bacteria suggests the use of carotenoids, yellow, orange and red cellular pigments, as UVR screening agents (Mathews \& Sistrom, 1959; Dworkin \& Stanley, 2006). UVR screening agents also provide protection from oxidation damage, which can be an indirect effect of UVR. On the other hand, Gascon et al. (1995) and 
Lewis et al. (1973) both found that pigmentation had little effect on UVR resistance. In addition, Arrage et al. (1993a) found a positive correlation between UVR resistance and Gram-positive status, suggesting that the thicker cell walls of Gram-positive microorganisms can screen a larger amount of the UVR compared to Gram-negative microorganisms. Along with UVR screening agents, bacteria can repair DNA damage using the light-independent repair systems: excision repair, post-replication repair and SOS repair. The excision repair system removes and replaces lesions with undamaged monomers prior to replication, while the recombination or post-replication repair system repairs gaps in daughter strands after DNA synthesis. Finally, the SOS system, mediated by the recA gene, reduces the fidelity of DNA polymerase III so it bypasses damaged nucleotides (Booth et al., 2001; Miller 2000). In addition, bacterial DNA can be repaired using the light-dependent repair mechanisms, which are initiated by exposure to UVR. In the dark zones of caves, this mechanism will be ineffective since there is no light to initiate this repair system.

We hypothesize that these protection and repair mechanisms, if not related directly to other essential functions, will degenerate over time in troglobitic bacteria (i.e., bacteria adapted to living in the dark zone of the cave environment; Langecker, 2000). Even surface organisms have great sensitivity to UVR, which has led to its use at high levels (0.8 to $1.8 \mathrm{~J}$ $-\mathrm{cm}^{2}$ ) to control contaminating cyanobacterial growth on stalactites in tourist caves (Dor \& Dor, 1999). However, in a comparative study of subsurface and surface bacteria, Arrage et al. (1993a) found a similar level of UVR resistance (26\% and $31 \%$, respectively) in surface bacterial isolates and bacterial isolates from drill sites between 150 and 500 meters below the surface when UVR resistance was defined as a survival rate of $>1 \%$ after UVC exposure. They concluded that deep subsurface bacterial isolates had conserved UVR protection and dark repair mechanisms. The results of Arrage et al. (1993a) could be explained by the bacteria's ability to repair damage caused by nonUVR environmental insults, such as reactive oxygen species (ROS). In a related study, Arrage et al. (1993b) found that microaerophilic deep subsurface bacterial isolates were less UVR resistant than the aerobic deep subsurface bacterial isolates.

The possible degeneration of UVR related enzymatic DNA repair and protection systems in bacteria in caves could help scientists better understand how microorganisms adapt to the cave environment and could serve as a marker for cave adaptation. If microorganisms show adaptation to darkness in the cave environment, this would suggest that cave microbial phenotypes exist. The loss of such mechanisms would also imply that they do not serve critical alternative functions in those organisms. This hypothesis suggests the following questions:

On average, do cave microorganisms have less resistance to UVR than microorganisms from the surface, as shown by survival after various amounts of UVR exposure?
Are the cellular characteristics microorganisms use to protect themselves from UV radiation, such as pigmentation, reduced or absent in the cave microorganisms compared to surface microorganisms?

We hypothesize that cave-adapted microorganisms have lost some of their UVR resistance, given that there is stronger selective pressure to reduce energy usage than to retain the ability to deal with UVR (Jagger, 1985).

In this study, we have focused on determining whether there is a significant difference between Carlsbad Cavern cave organisms and organisms from overlying soils with respect to UVR sensitivity as observable in cultured isolates. We determined cell survival to estimate the efficiency of the lightindependent DNA repair capacity of cave organisms following exposure to UVR. In our tested isolates, we also documented Gram status (as an indicator of wall robustness) and pigmentation, traits potentially implicated in possible protection against UVR.

\section{MATERIALS AND METHODS}

\section{Site Description and Bacterial Isolation}

Cave bacterial isolates were collected from areas of moonmilk (a pasty, unconsolidated mineral material often associated with significant microbial activity, e.g. Hill \& Forti, 1997; Gradzinski et al., 1997; Northup et al., 2000), flowstone, and an iron-rich pool located in Left Hand Tunnel (at a depth of 230 $\mathrm{m})$ in the dark zone of Carlsbad Cavern in Carlsbad Caverns National Park (CCNP), New Mexico, U.S.A., as described in Table 1 and Fig 1. Surface samples were collected from around the seldom visited second entrance to Carlsbad Cavern and from a distant control site of surface rocks outside of Castetter Hall at University of New Mexico. All cave sampling sites were at least three meters from the tourist path, where no permanent light sources were used; caver headlamps (which emit light at wavelengths above the UVR spectrum at a intensity of 0.7 to $8 \mathrm{~lm} / \mathrm{ft}^{2}$ ) used by researchers occasionally visiting the site and candlelight lamps (with a intensity of $0.007 \mathrm{~lm} / \mathrm{ft}^{2}$ ) from limited park tours were the only light exposure to which native bacteria were exposed.

Cave and surface samples were inoculated onto BD Difco R2A medium (Becton, Dichinson, Sparks, MD) and Luria Broth medium (LB, Difco, Becton, Dickinson, Sparks, MD) respectively on site using sterile rayontipped swabs rubbed over a $1 \mathrm{~cm}^{2}$ area and then spread over the entire plate surface or by spread-plating 0.1 $\mathrm{ml}$ of pool water obtained with sterile syringes. Cave cultures were then incubated for 24 hours in the dark on site in Left Hand Tunnel of Carlsbad Cavern. During all transportation, the cultures were wrapped in aluminum foil to reduce the amount of light exposure. Once in the lab, monocultures of cave and surface isolates were created and incubated in the dark at $15^{\circ} \mathrm{C}$ and $37^{\circ} \mathrm{C}$, respectively. Twenty-two cave isolates and 22 surface isolates ( 11 from each of the above mentioned collecting locations) were selected to maximize possible culturable morphologies in the study. 
Table 1. Summary of sampling sites for the 22 cave bacterial isolates used in UVR irradiation study.

\begin{tabular}{|c|c|}
\hline Sample Number & Location collected \\
\hline CCA2 & Iron Pool Water \\
\hline CCB1 & Iron Pool Water \\
\hline CCB3 & Moonmilk \\
\hline CCB4 & Iron Pool Water \\
\hline CCC1 & Pool Water \\
\hline CCC2 & Moonmilk \\
\hline CCC3 & Iron Pool Water \\
\hline CCC4 & Pool Water \\
\hline CCD1 & Iron Pool Water \\
\hline CCD2 & Iron Pool Water \\
\hline CCE1 & Swab of Moonmilk \\
\hline CCE2 & Moonmilk \\
\hline CCE3 & Moonmilk \\
\hline CCE4 & Iron Pool Water \\
\hline CCF1 & Swab of Pool with floating Moonmilk \\
\hline CCF2 & Swab of flowstone \\
\hline CCF3 & Swab of flowstone \\
\hline
\end{tabular}

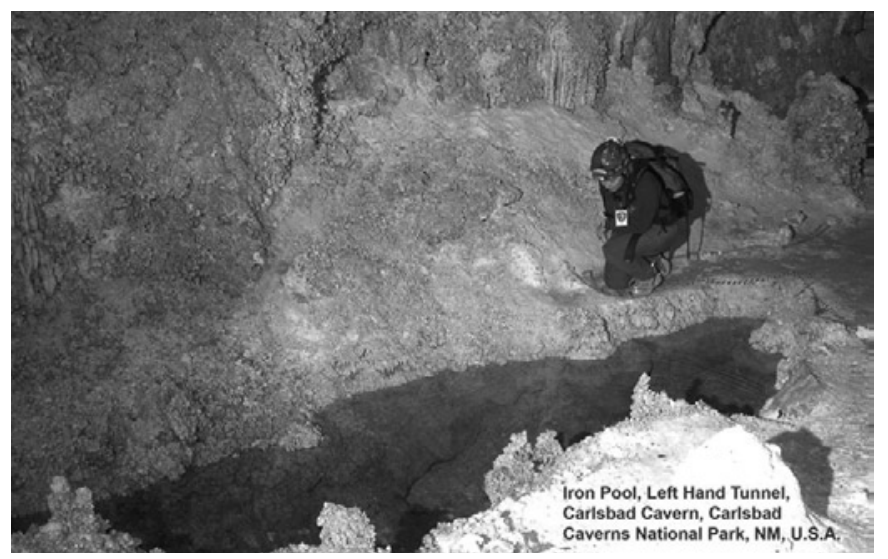

Fig 1. Iron Pool in Left Hand Tunnel, Carlsbad Cavern, Carlsbad, NM. Notice the yellow color of iron pool.

\section{UVR Irradiation Studies}

Surface area and colony forming unit (CFU) measurements were completed on surface and cave bacterial isolates grown on R2A or LB. Total exposures were calculated using the exact irradiance output of our Biological Safety Cabinet $\left(200 \mu \mathrm{W} / \mathrm{cm}^{2}\right)$ as measured by a UVP Model UVX Digital UV Radiometer multiplied by the amount of time they were irradiated $(0,50$ or 100 seconds). Isolates were inoculated onto plates using standard spread plate (CFU) or streak plate (surface area) methods and exposed to UVR with lids off at room temperature. Triplicates of isolates were exposed to $0 \mu \mathrm{Ws} / \mathrm{cm}^{2}$ of UVR (control group), $10,000 \mu \mathrm{Ws} / \mathrm{cm}^{2}$ of UVR and $20,000 \mu \mathrm{Ws} / \mathrm{cm}^{2}$ of UVR in a laboratory biological safety cabinet. Subsequent to exposure, isolates were immediately wrapped in aluminum foil for transport between the incubator and biological safety cabinet to eliminate light repair system activation (Simonson et al., 1990) and were incubated in the dark at their respective temperatures for six days.

For the surface area measurements, streaks of each isolate were photographed and surface area growth was measured using NIH Imager 3.6.1. For CFU measurements, CFU were computed for each isolate for each of the UVR treatments. Triplicates were averaged. Percent survival was calculated using the following equation: Percent survival $=$ surface area or $\mathrm{CFU}$ of post-treatment growth/surface area or CFU of control growth.

\section{Pigmentation and Gram Status Determination}

Pigmentation was determined using pure cultures grown on R2A. Isolates were assigned different pigmentation categories: (1) low (no pigmentation noticeable macroscopically), (2) medium (colonies had a whitish to tan coloration with some opaqueness visible macroscopically) or (3) high (bright, solid colors from bright white to pink or purple visible macroscopically). In order to check for changes in pigmentation in differing conditions, controls were grown in the light. No pigmentation change was noted in colonies grown on R2A after two weeks of growth in lighted conditions. The only pigmentation change noticed was slightly brighter pigmentation when some samples were grown on LB media. Gram status was determined using standard Gram staining procedure, as described in Lammert (2007).

\section{Statistical Analysis of Data}

All statistical analyses were completed using Minitab 15. For pigmentation and sensitivity analyses, results were compared using a Fisher two-proportion or Chi square test. Results of the irradiation studies were tested for normality using the AndersonDarling test and compared using a Kuskal-Wallis non-parametric test. Differences were considered significant based on a $95 \%$ confidence level.

\section{Survival Curve Study}

Surface samples B2 and B3 and cave samples B1, B4, C3, E3 and F3 were selected to undergo survival curve analyses. Two-hundred-fifty microliters of an overnight culture were used to inoculate $20 \mathrm{~mL}$ of R2B broth in a side-arm flask. The flask was placed on a shaker at room temperature and the growth rate measured every hour using a spectrophotometer. When the $\mathrm{OD}_{660}$ reached 0.8 , then $10 \mathrm{~mL}$ of the culture were pelleted at $10,000 \mathrm{x} g$ and resuspended in $10 \mathrm{~mL}$ of sterile saline. This solution was placed in a sterile Petri dish and exposed to increasing doses from 0 to $100 \mathrm{~J} / \mathrm{m}^{2}$ of UVR radiation generated by UV bench lamps (Simonson et al., 1990). Exposure was begun by removing the glass Petri dish lid and terminated by replacing it. Doses were quantified using a UVX Radiometer (UVP, Inc., Upland, CA). At each UVR dose, $0.1 \mathrm{~mL}$ of sample were serially diluted in saline medium and plated. The dilution plates were incubated at room temperature in the dark for 48-72 hours and the resulting colonies counted.

UV Sensitivity Coefficient: The UV Sensitivity Coefficient $\left(\mathrm{S}_{\mathrm{UV}}\right)$ was calculated by the method of Simonson et al. (1990) from the formula:

$\mathrm{S}_{\mathrm{Uv}}=\ln \left[(\mathrm{CFU})_{\mathrm{d}} /(\mathrm{CFU})_{0}\right] / \mathrm{d}$ where $(\mathrm{CFU})_{0}$ is the 
concentration of CFU in unexposed samples and the $(\mathrm{CFU})_{\mathrm{d}}$ is the recoverable concentration after exposure to dose (d) of UV radiation. The dose (d) is expressed in $\mathrm{J} / \mathrm{m}^{2}$. By this method, the more negative the coefficient, the more sensitive a particular strain is to $\mathrm{UVC}$ radiation.

\section{Phylogenetic Analysis of Cave Samples}

DNA from the cave bacterial pure cultures was extracted using MoBio UltraClean DNA Extraction Kit. The 16S rRNA gene was amplified using universal bacterial primers 46F (GCY TAA YAC ATG CAA GTC G) and 1409R (GTG ACG GGC RGT GTG TRC AA) with an amplification reaction mixture containing $30 \mathrm{mM}$ Tris- $\mathrm{HCl}$ (pH 8.3), $50 \mathrm{mM} \mathrm{KCl,} 1.5 \mathrm{mM} \mathrm{MgCl2,} 5 \mathrm{mg}$ bovine serum albumin (Boehringer- Mannheim), 200 $\mathrm{mM}$ (each) deoxynucleoside triphosphates, $100 \mathrm{pmol}$ of each primer and $5 \mathrm{U}$ of Taq polymerase (AmpliTaq LD; Perkin-Elmer) in a final reaction volume of $25 \mu 1$. PCR was conducted with a $\mathrm{MJ}$ thermal cycler as follows: 4 min denaturation at $94^{\circ} \mathrm{C}$, followed by 35 cycles of $45 \mathrm{~s}$ annealing at $55^{\circ} \mathrm{C}, 2 \mathrm{~min}$ at $72^{\circ} \mathrm{C}$ (extension), and $30 \mathrm{~s}$ at $94^{\circ} \mathrm{C}$ (denaturation), with a final $45 \mathrm{~s}$ $50^{\circ} \mathrm{C}$ annealing and $20 \mathrm{~min} 72^{\circ} \mathrm{C}$ extension step after cycling was complete. Product was further cleaned with Exosap treatment (USB Corporation, Cleveland, $\mathrm{OH})$, and sequenced using ABI PRISM Big Dye Terminator v1.1 sequencing kit (Perkin-Elmer, Foster City, CA). Orientation was checked using Orientation Checker (http://www.bioinformatics-toolkit.org/ Downloads/index.html) and sequences were screened for possible chimeric artifacts using Mallard (http:// www.bioinformatics-toolkit.org, Ashelford et al., 2006). Closest relatives of genetic sequences from the cave isolates were selected using NCBI Blast (NCBI, Altschul et al., 1997). Sequences of $650 \mathrm{bp}$ were aligned using GreenGenes (http://greengenes.lbl.gov/cgi-bin/nph-index.cgi) and manually refined using BioEdit multiple sequence editor (http://www.mbio.ncsu.edu/BioEdit/ BioEdit.html). An unweighted maximum parsimony phylogenetic analysis was performed using PAUP version 4.0b10. Bootstrap analyses were conducted on 1000 resample datasets.

\section{RESULTS}

\section{UVR Irradiation Studies}

Cave bacteria from Carlsbad Cavern grown on either R2A or LB showed a higher level of sensitivity to UVR than surface isolates, although the level and significance of this difference varied. In general, the difference between the surface and cave isolates was most pronounced at the lower irradiation levels or when grown on the higher nutrient medium (i.e. LB). These trends were consistent whether we measured using surface area or CFU to determine by percent survival.

\section{Surface Area Growth Measurements to Determine Percent Survival}

Percent survival of cave and surface isolates grown on low nutrient medium (R2A) was similar when exposed to $10,000 \mu \mathrm{Ws} / \mathrm{cm}^{2}$ of UVR (Fig 2). Cave

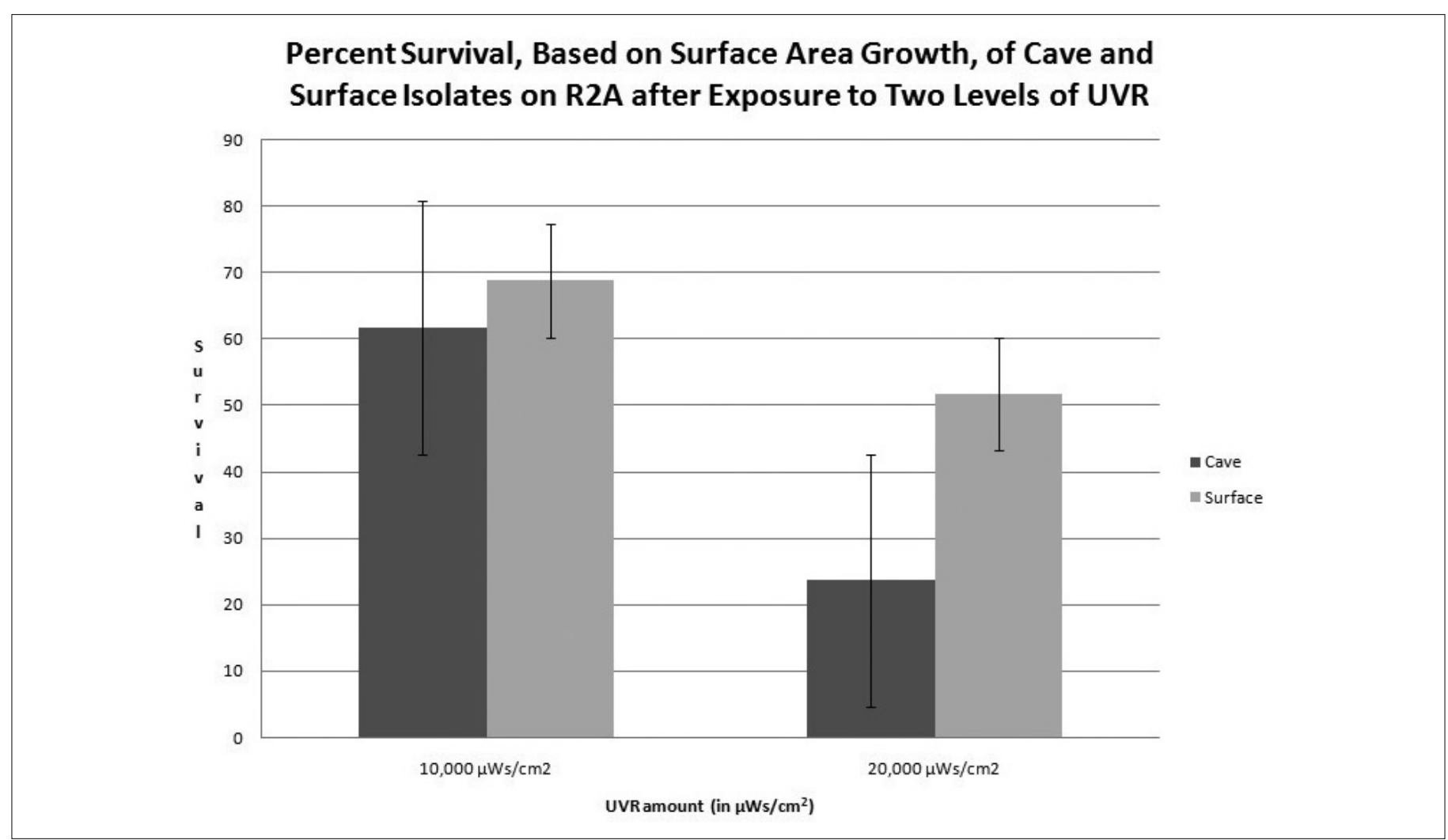

Fig 2. Percent survival based on surface area growth, of cave and surface isolates on R2A after exposure to two levels of UVR. Note that percent survivals of surface and cave pure culture isolates were not significantly different after a UVR treatment of 10,000 $\mathrm{WW} / \mathrm{cm}^{2}$. After a UVR treatment of $20,000 \mu \mathrm{Ws} / \mathrm{cm}^{2}$, the cave isolates had a lower percent survival than surface isolates; however, this difference is not significant at the $95 \%$ confidence level. Data represent the mean percent survival of cave and surface isolates $\pm \mathrm{SE}$. This information was calculated from an average of all tested isolates after exposure to UVR in an open (no lid on) media plate in a biological safety cabinet. 
isolates had a mean percent survival of $64.48 \%$ $( \pm 35.42)$, while surface isolates had a mean percent survival of $75.00 \%$ ( \pm 20.23 ). Percent survival of cave and surface isolates was not statistically different after $20,000 \mu \mathrm{Ws} / \mathrm{cm}^{2}$ of UV exposure; Cave isolates showed a $24.75 \%( \pm 19.38)$ survival while surface isolates had a survival of $56.40 \%( \pm 50.7)$. Interestingly, several cave and surface isolates showed greater than $100 \%$ growth after 10,000 and $20,000 \mu \mathrm{Ws} / \mathrm{cm}^{2}$ on R2A.

When grown on a high nutrient medium, the differences in sensitivities of cave and surface isolates were significant, as shown in Fig 3. After 10,000 $\mu \mathrm{Ws} /$ $\mathrm{cm}^{2}$ the percent survival of cave and surface isolates showed a statistically significant difference $(P \leq 0.05)$, with $85.00 \%( \pm 52.1)$ and $173.8 \%( \pm 145.20)$ survival, respectively. Very interesting is the greater than $100 \%$ survival of the surface isolates after $10,000 \mu \mathrm{Ws} / \mathrm{cm}^{2} \mathrm{UV}$ exposure. After $20,000 \mu \mathrm{Ws} / \mathrm{cm}^{2}$ of UV exposure, the cave and surface isolates showed a significant difference $(P \leq 0.05)$ in percent survival. Cave samples showed a mean of $37.84 \%( \pm 25.06)$ survival, while surface samples showed an average of $100.30 \%( \pm 67.3)$ survival.

\section{CFU Measurements to Determine Percent Survival}

CFU results show a significantly lower percent survival in cave samples $(P \leq 0.05)$ than surface isolates after 10,000 and $20,000 \mu \mathrm{Ws} / \mathrm{cm}^{2}$ of UV exposure on R2A, as shown in Fig 4. Cave isolates exhibited a mean percent survival of $0.1359( \pm 0.2751)$ after $10,000 \mu \mathrm{Ws} /$ $\mathrm{cm}^{2}$ exposure, while surface isolates showed a mean percent survival of $33.50( \pm 25.90)$. After $20,000 \mu \mathrm{Ws} /$ $\mathrm{cm}^{2}$ of UV exposure, cave isolates showed a mean of $2.1 \times 10^{-3} \%( \pm 0.0031)$ survival, while surface isolates showed a mean of $0.751 \%( \pm 0.606)$ survival.

When grown on the high nutrient medium (LB), there was a significant difference between cave and surface isolate survival after $10,000 \mu \mathrm{Ws} / \mathrm{cm}^{2}$ but not after $20,000 \mu \mathrm{Ws} / \mathrm{cm}^{2}$. When exposed to $10,000 \mu \mathrm{Ws} / \mathrm{cm}^{2}$ of $\mathrm{UV}$, cave isolates showed a mean of percent survival of $0.333 \%( \pm 0.334)$, while surface isolates showed a mean of $88.30 \%( \pm 136.10)$ survival. However, after $20,000 \mu \mathrm{Ws} / \mathrm{cm}^{2}$ of UV exposure, the cave and surface isolates showed a mean survival of $2.3 \times 10^{-2} \%( \pm 0.018)$ and $4.39 \%( \pm 5.02)$, respectively.

\section{Percent Survival, Based on Surface Area Growth of Cave and Surface Isolates on LB after Exposure to Two Levels of UVR}

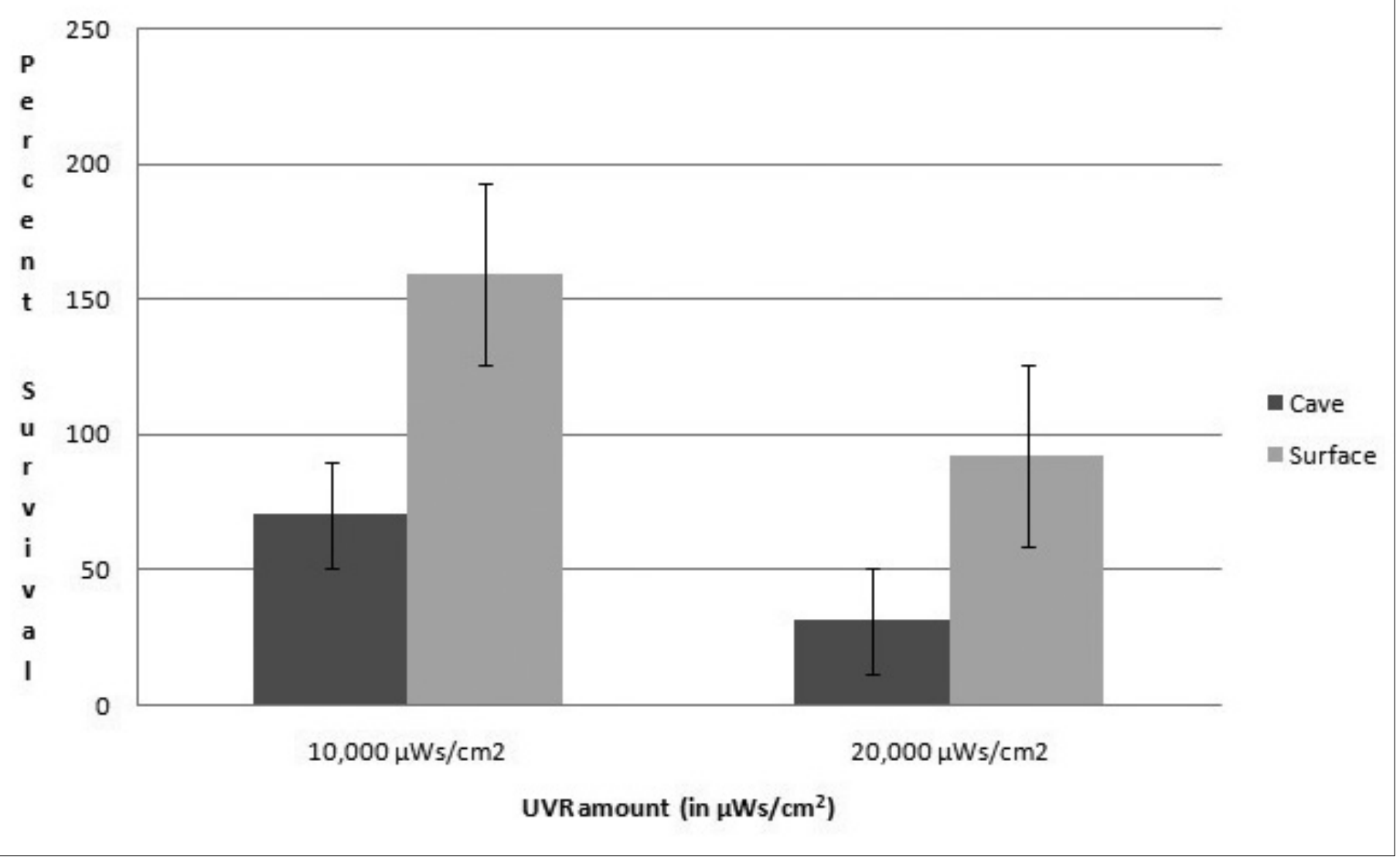

Fig 3. Percent survival, based on surface area growth, of cave and surface isolates on LB after exposure to two levels of UVR. Note that after UVR treatments of $10,000 \mu \mathrm{Ws} / \mathrm{cm} 2$ and $20,000 \mu \mathrm{Ws} / \mathrm{cm}^{2}$, there were significant differences between the percent survival of the cave and the surface pure culture isolates. After $10,000 \mu \mathrm{Ws} / \mathrm{cm}^{2}$ of UVR, the surface isolates actually had an increase in percent survival. Percent survival higher than $100 \%$ is not seen on the R2A or after $20,000 \mu \mathrm{Ws} / \mathrm{cm}^{2}$ UVR treatment. Data represent the mean percent survival of cave and surface isolates \pm SE. This information was calculated from an average of all tested isolates after exposure to UVR in an open (no lid on) media plate in a biological safety cabinet. 


\section{Percent Survival, Based on CFU Measurements, of Cave and Surface Isolates on LB and R2A after Two Levels of UVR}

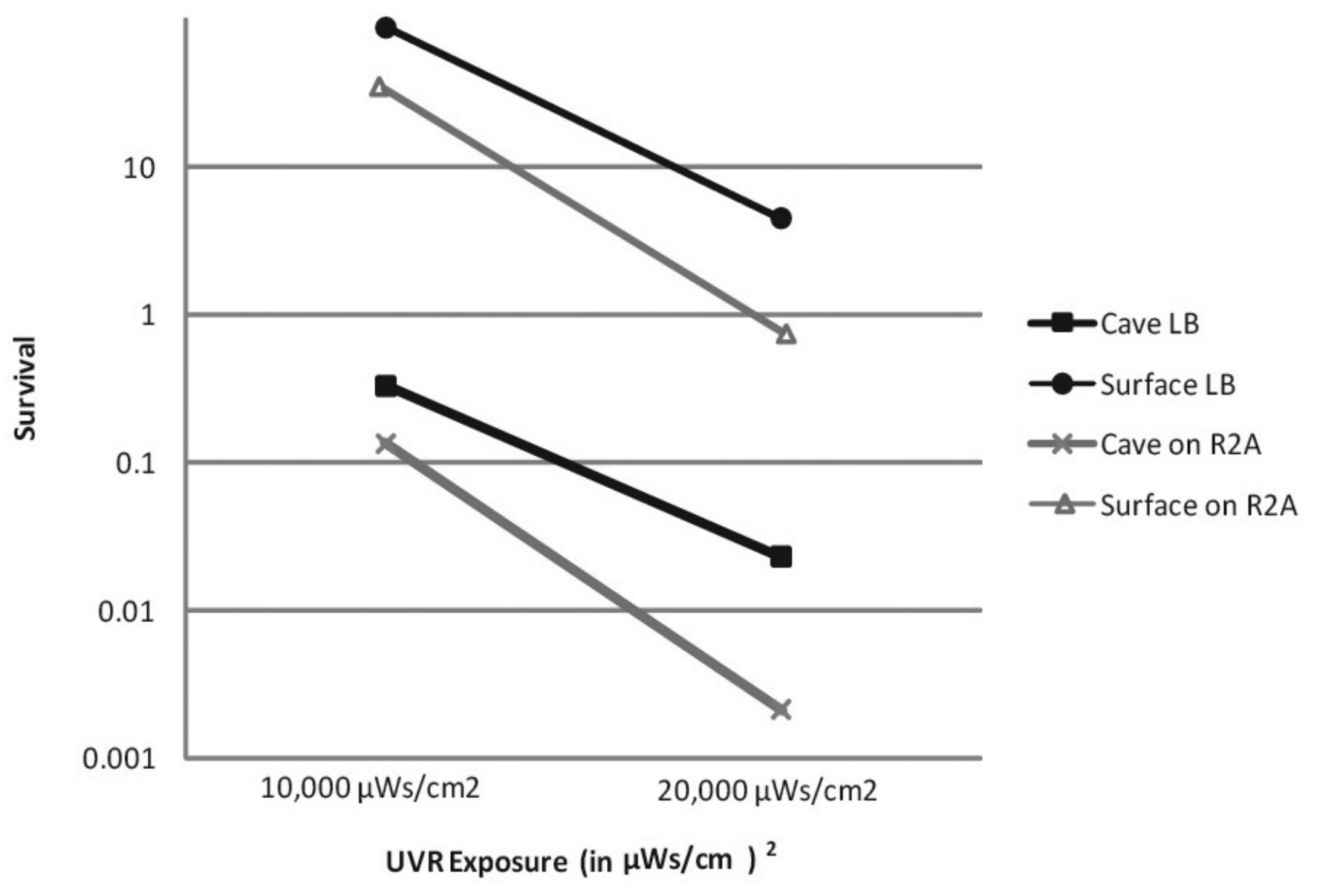

Fig 4. Percent survival, based on colony forming unit measurements, of cave and surface isolates on LB and R2A after two levels of UVR. These data are plotted on a log scale. Note that on the cave isolates had a significantly lower percent survival on both LB and R2A. In addition, cave and surface isolates had lower percent survival amounts when grown on R2A, the low nutrient medium, than when grown on LB, the high nutrient medium. Data represent the mean percent survival of cave and surface isolates $\pm S E$. This information was calculated from an average of all tested isolates after exposure to UVR in an open (no lid on) media plate in a biological safety cabinet.

Although we see a fairly large difference in the percent survival of the two different sets of bacterial isolates at this level of UV treatment, we believe they are not considered significantly different because of the large standard deviation of the surface isolates (5.02).

\section{Cellular Characteristics (Pigmentation and Gram Status)}

Using pigmentation categories described above, our results showed that the surface bacteria isolates were $63.6 \%$ highly pigmented, while only one $(4.5 \%)$ of the surface isolates was classified as having low pigmentation. In contrast, the cave bacterial isolates showed $35 \%, 35 \%$ and $30.4 \%$, respectively, for the low, medium and high pigmentation types (Fig 5).

To further examine this relationship, we compared the pigmentation level of the isolates to their sensitivity to UVR. Sensitivity to UVR was defined as $<1.0 \%$ survival on low nutrient media after a UVR treatment of $10,000 \mu \mathrm{Ws} / \mathrm{cm}^{2}$ using CFU measurements. For any surface area measurements used (used only when CFU measurements were unavailable), we defined sensitivity to UVR as $<50 \%$ survival on low nutrient media after a treatment of $10,000 \mu \mathrm{Ws} / \mathrm{cm}^{2}$. Results showed that while $100 \%$ of the cave isolates were sensitive to UVR, only $36 \%$ of the surface isolates were sensitive to UVR. When pigmentation and sensitivity levels were correlated, we found that highly pigmented isolates could be sensitive or insensitive to UVR, with most of the highly pigmented isolates being insensitive. However, all low pigmented isolates were sensitive to some degree to UVR (Table 2).

In this study, we found that $50 \%$ of the surface isolates were Gram-positive, while only $25 \%$ of the cave isolates were Gram-positive. While we did not see a clear predominance of Gram-positive cells in the surface isolates, a majority of cave isolates were Gram-negative. 


\section{Pigmentation of Cave and Surface Isolates}
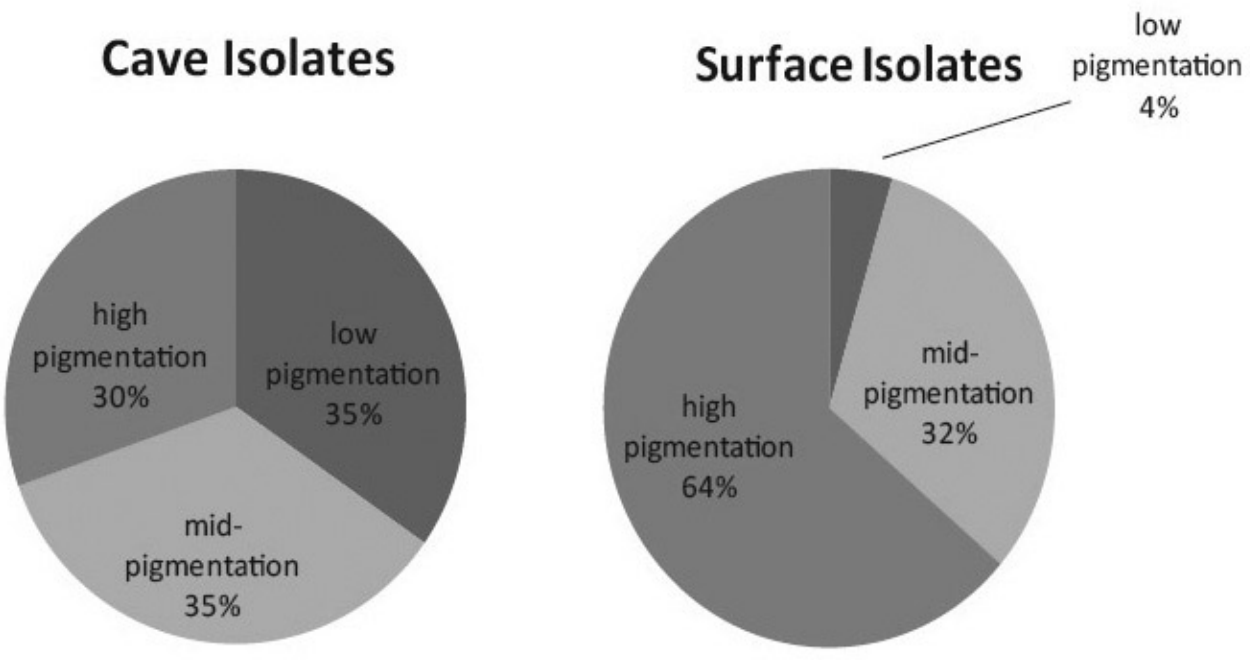

Fig 5. Pigmentation levels of cave and rurface isolates. Pigmentation level was based on colony coloration when grown on R2A. Low pigmentation meant no pigment was noticeable. Medium (mid) pigmentation meant that colonies had a white or tan opaqueness, while high pigmentation meant that colonies had bright, solid colors, such as purple, pink, yellow, or white.

Table 2. Correlation of Pigmentation and Sensitivity in Surface and Cave Isolates. Sensitivity when determined by CFU measurements was defined as $<1.0 \%$ survival after a UV treatment of $10,000 \mu \mathrm{Ws} /$ $\mathrm{cm}^{2}$ when grown on R2A. Sensitivity when determined by surface area measurement was defined as $<50 \%$ survival after a UV treatment of $10,000 \mu \mathrm{Ws} / \mathrm{cm}^{2}$ when grown on R2A. Note that isolates with high levels of pigmentation varied in whether they were sensitive or resistant to UVR, but no isolates with low levels of pigmentation were resistant (i.e. not sensitive) to UVR.

\begin{tabular}{|c|c|}
\hline Pigmentation / sensitivity level & \# of clones with \\
\hline High Pigmentation/sensitive & 5 \\
\hline High Pigmentation/not sensitive & 9 \\
\hline Low Pigmentation/sensitive & 8 \\
\hline Low Pigmentation/not sensitive & 0 \\
\hline
\end{tabular}

\section{Survival following various doses of UVC radiation}

Survival rates were determined for selected surface and cave isolates as described in the materials and methods (Fig 6). In general, surface organisms showed higher rates of survivability than did cave organisms, although the ranges of resistance to killing by UVC varied greatly and these results are not statically significant. The $\mathrm{S}_{\mathrm{UV}}$ (Simmonson et al. 1990) for these organisms (Table 3) indicates their reduced ability to survive following UVC exposure. Note that the more negative the $\mathrm{S}_{\mathrm{UV}}$ for an organism, the more sensitive that organism is to UV radiation.

\section{Phylogenetic Analysis of Cave Samples}

We were able to sequence only 16 of the 22 cave isolates in the experiment. Of these, seven of the isolates grouped with the Actinobacteria, while the other nine grouped with the Proteobacteria. In the Proteobacteria, two grouped with the Alphaproteobacteria, two grouped with the Betaproteobacteria and five grouped with the Gammproteobacteria. Three pairs of sequences, B1 and D2, A2 and D4, and B4 and E2, showed a 98\% similarity to each other when compared in BioEdit, suggesting that they are the same species. Given this, we decided to treat the isolates in each of these three pairs as the same species for the rest of the analysis. After each closest relative description below, the percent similarity as determined by BioEdit is listed in parenthesis.

Several of the cave isolates grouped within Actinobacteria, as shown in Fig 7. Cave isolate F3 was most closely related to Knoellia subterranea, a bacterial isolate from Reed Flute Cave in Guangxi, China (84\% similarity) (Groth et al., 2002) and a Tetrasphaera species found in soils (85\% similarity). Cave isolate B4 was most closely related to a Microbacterium species found in deep-sea vents $(72 \%$ similarity) and an uncultured clone found in arctic sea ice $(72 \%$ similarity). Of particular interest is the closest relative to $\mathrm{B} 4$, Microbacterium phyllosphaerae, a bacterial isolate from an Etruscan tomb $(71 \%$ similarity). Cave isolate E3 was closely related to a Rhodococcus species from the same tomb $(81 \%$ similarity). Finally, cave isolate C2 was most closely related to two different Rhodococcus species (96\% similarity), both from saline environments, such as deep ocean sediment and haloalkaline environments.

The rest of the bacterial isolates grouped within the Proteobacteria, with representatives from the Alpha-, Beta- and Gammaproteobacteria. As shown in Fig 7, cave isolate B1 was most closely related to Pseudomonas species found in heavy metal contaminated waters (99\% similarity), while cave isolate B3 was most closely related to Xanthomonas (87\% similarity) and Pseudomonas species (87\% similarity), both found 


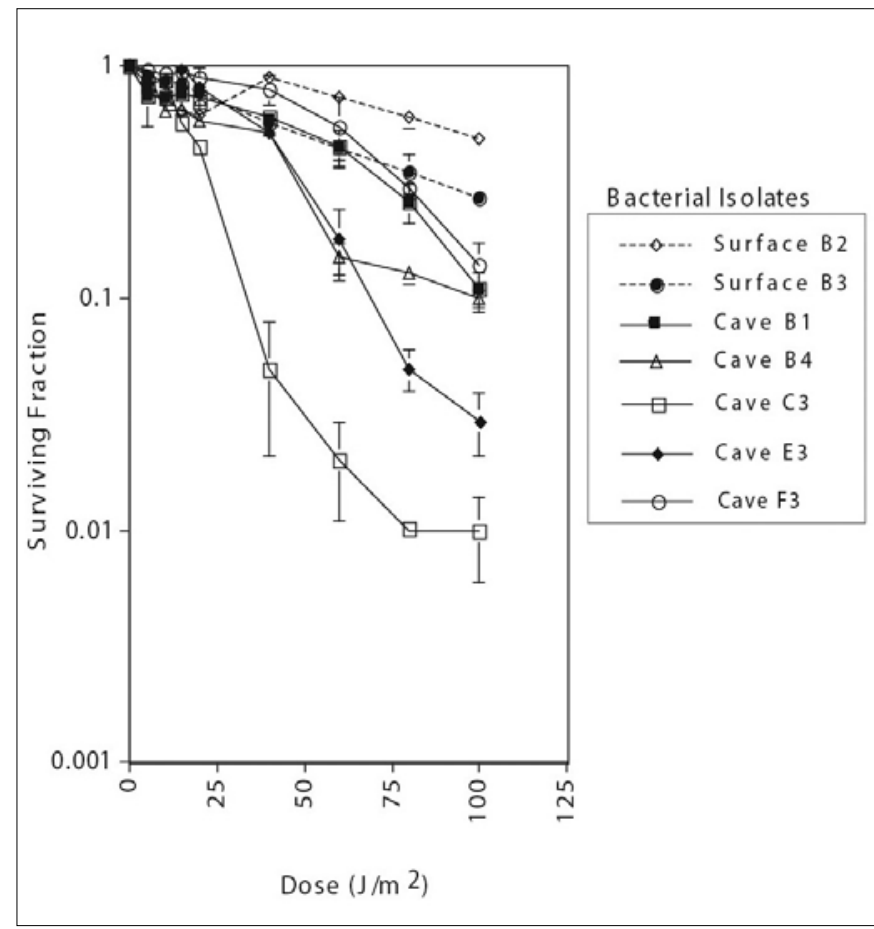

Fig 6. Survival rates following various doses of UVC radiation. Data represent the mean of at least five experiments \pm SE.

Table 3. Sensitivity of various strains to UVC irradiation. UV Sensitivity Coefficients (SUV) were calculated from the average percent survival at $100 \mathrm{~J} / \mathrm{m}^{2}$ using the formula of Simonson et al. (1990).

\begin{tabular}{|c|c|c|c|}
\hline \multicolumn{2}{|c|}{ Strain } & $\begin{array}{c}\text { Percent survival at } \\
100 ~ J_{\mathbf{m}^{2}}\end{array}$ & $\mathbf{S}_{\mathrm{uv}}$ \\
\hline Surface & B2 & 49 & -0.007 \\
\hline & B3 & 27 & -0.013 \\
\hline Cave & B1 & 12 & -0.021 \\
\hline & B4 & 10 & -0.029 \\
\hline & C3 & 1 & -0.056 \\
\hline & E3 & 3 & -0.035 \\
\hline & F3 & 13 & -0.020 \\
\hline
\end{tabular}

in alpine soils. Cave isolates D4 was found to be most closely related to an environmental isolate found in the Elbe River snow (94\% silimarity) and a Chitinimonas species found in a warm spring in India (96\% similarity).

Although not listed in the tree due to limited sequencing success, both cave isolates C3 and E1 grouped with Alphaproteobacteria. Specifically, cave isolate C3 was most closely related to Sphingomonas species found in a marine oligotrophic environment (98\% similarity as determined by BLAST) and a bacterium found in Kartchner Caverns (Arizona, USA) (97\% similarity as determined by BLAST)

\section{DISCUSSION}

One of the strongest selective pressures in the cave environment is the need to conserve energy in the typically oligotrophic cave. The physical conditions in Carlsbad Cavern, such as constant darkness, constant temperatures $\left(15-18^{\circ} \mathrm{C}\right.$ depending on depth) a relatively constant humidity of $95-100 \%$ and little organic input from the surface during the current climatic era, have resulted in some macroinvertebrate organisms exhibiting reduced pigmentation, lower rates of metabolism (Northup et al., 1993), reduced or absent eyes, and enhanced non-visual sensory apparati (Culver, 1982). We have hypothesized that cave-adapted microorganisms will show analogous adaptations to the cave environment, resulting in a cave-specific bacterial phenotype that has reduced pigmentation, longer generation times and reduced ability to deal with the effects of UVR. At this point, we cannot yet distinguish whether this is an evolutionary change in the composition of the population or whether it is a physiological adaptation that could be reversed by growing organisms once again in a lighted environment. This is particularly true since we are working only with culturable organisms and nonculturable community members were not studied.

It is highly unlikely that we are dealing with surface organisms that have been recently relocated to Left Hand Tunnel and have survived in the oligotrophic conditions. Airflow between the surface and the sampling site in Left Hand Tunnel is limited as the site is 230 meters below the surface and over a kilometer away from the entrance. Visitor access occurs, but much less than in the main touristaccessible passages, and only on ranger-led tours. An additional indication that we are observing caveadapted members of a subsurface biota is that some of our study microorganisms grouped with other isolates from subsurface biota that have been found in other caves or subsurface environments but rarely related to surface relatives. These include Knoellia subterranea from a cave in China, a bacterial clone from Kartchner Caverns in Arizona, USA and two microorganisms from a subterranean tomb in Italy. Primarily, we have found Actinobacteria and Proteobacteria, two phyla commonly found in limestone and basaltic caves, and in nearby locations in this cave (Barton et al., 2007, Northup et al., 2008). In addition, a number of our microorganisms grouped with closest relatives from alpine or frozen soils. One can only speculate that such relatives originally might have been introduced into the Carlsbad system during much different, wetter, colder surface climatic regimes (e.g., seven glacial eras during the Pleistocene Epoch, from 1.8 $\mathrm{M}$ to $11.5 \mathrm{Ky}$ ago). The sampling locations in Left Hand Tunnel have a stable temperature of $15^{\circ} \mathrm{C}$, an environment suitable for organisms that are psychrotolerant. Finally, samples were collected from areas three meters from the trail to minimize impact from the limited visitation that occurs.

As expected, we found that some microorganisms have reduced ability to survive and grow after UVR irradiation. Such UVR sensitivity may well be an indicator of cave adaptation, although there are obviously UVR sensitive organisms in surface environments. In spite of apparent sensitivity, all cave organisms did show significant ability to survive, which we believe is because of residual DNA repair capacity. Our experiments were done in such a way as to monitor repair capacity that does not require light as a cofactor (Miller, 2000; Miller et al., 1999). 


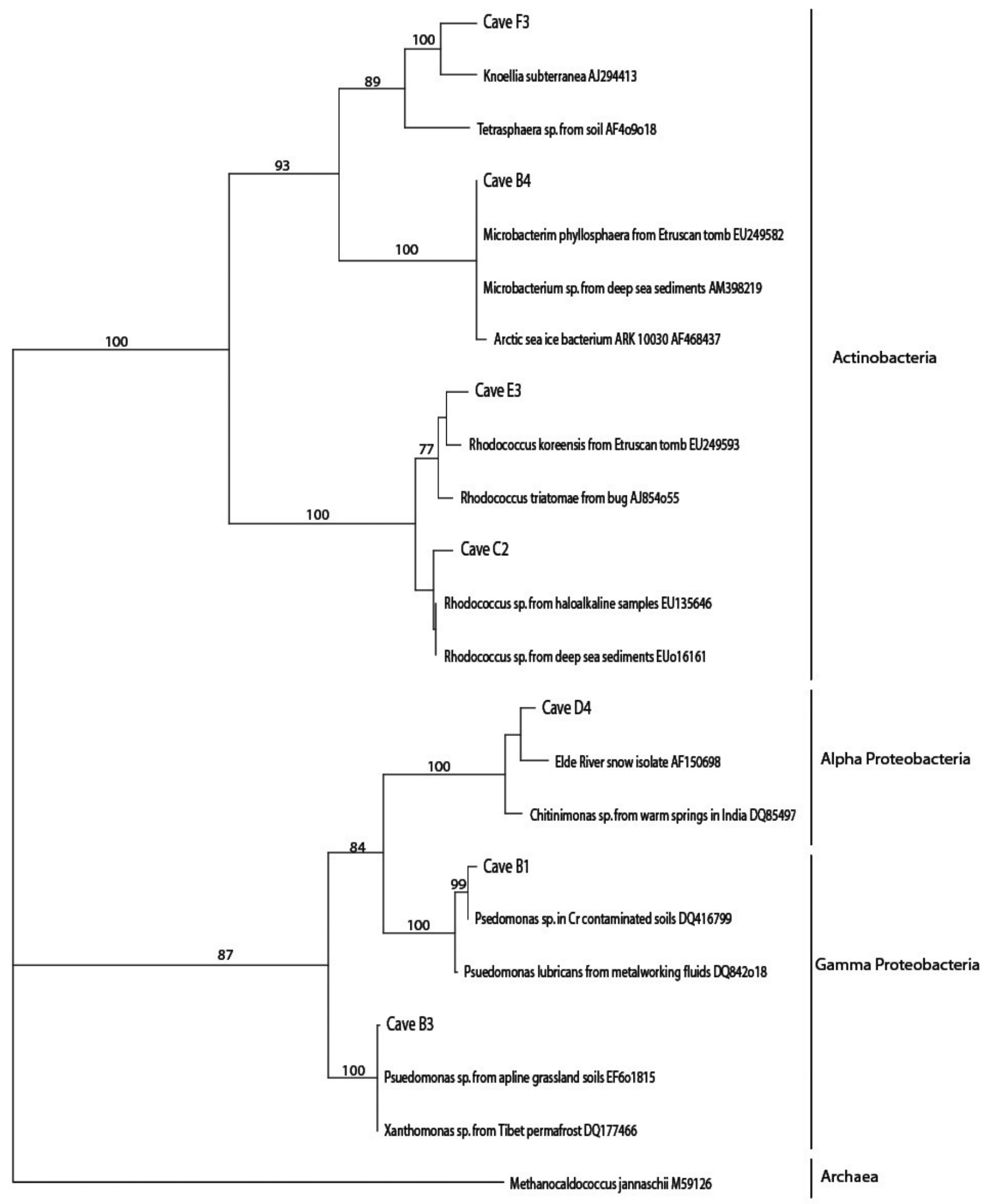

- 10 changes

Fig 7. Phylogram of cave bacterial isolates. Only sequences with $>650$ bp were included. Phylogenetic analysis was carried out using parsimonious (heuristic) searches, with robustness determined by 1000 replicate bootstrap analysis. 
These repair systems are needed to repair damage to DNA from various environmental and metabolic sources. It is not surprising that cave-adapted bacteria have retained some, although reduced, light-independent DNA repair mechanisms. It will be interesting to determine whether these organisms have retained photolyase, an enzyme that requires visible light to reverse the damage done by UVR and other cyclobutane-producing substances (Miller et al., 1999; Carell et al., 2001). However, effects of the photoreactivation repair process were not tested in this particular study, because we were focusing on specific mechanisms directly relevant to microorganisms living in the constant darkness of a cave environment.

Differences in UV sensitivity were less pronounced when isolates are grown on a low nutrient medium (R2A) more representative of the oligotrophic nature of the cave environment. We believe this is because the growth of surface isolates is limited by the low energy availability present in the media. However, when grown on a medium more representative of the higher surface nutrient loads (LB agar), surface bacterial isolates showed greatly increased abilities to recover from UVR irradiation. We hypothesize that this increase in growth after UVR irradiation is an effect of light-independent repair system activation. Such activation is able to function at its full potential in organisms adapted to the surface environment when grown on media with higher nutrient availabilities that surface environments typically offer. In addition, nonUV exposed control surface isolates had lower average CFU counts $\left(4.8 \times 10^{6}\right.$ colony forming units) than cave isolates $\left(1.8 \times 10^{8}\right.$ colony forming units) when grown on R2A. This is consistent with our belief that growth of surface isolates is limited by the reduced nutrient concentrations in R2A medium. However, it should be noted that R2A still has much higher organic nutrient concentrations than many other low nutrient media, such as water agar or mineral media with no organic carbon added.

Although our results show that cave isolates had a decreased ability to deal with UVR, other studies have not seen this trend (Arrage et al., 1993a). Both studies look at surface and subsurface microorganisms, but numerous differences exist, such as media on which isolates were grown, UV fluence $\left(\mu \mathrm{W} / \mathrm{cm}^{2}\right)$ rate and irradiation methods. In addition, we are looking at two significantly different microbial habitats (limestone cave versus deep rock with little to no airspace) at different depths (230m versus $500 \mathrm{~m})$. The evolutionary selection factors in these two environments and the geological residence times of the founding populations of organisms in those environments are unclear; thus, populations may differ radically in their evolutionary histories and subsequent development. Clearly further research in this area is needed to place the microbial communities in a meaningful geological context.

In addition to reduced survival following exposure to UVR, we noticed other cellular changes in our cave-adapted isolates. Pigmentation present in some bacterial cells absorbs potentially deleterious electromagnetic radiation and protects the bacterial DNA from the damaging effects of the UVR, resulting in a selective advantage to pigmented surface microorganisms. We found that while the surface bacterial isolates were primarily highly pigmented, there was relatively even distribution amongst the cave isolates into highly pigmented, moderately pigmented, or low or no pigmented strains. Given that limited resources are a strong selective pressure in the cave environment, it would not be surprising that over time, as bacterial isolates become more cave-adapted, they would benefit energetically by losing no longer essential pigmentation, thus not paying the cost of maintaining this trait. However, additional research is needed to determine if this loss of pigmentation is an evolutionary change or a reversible physiological adaptation and to investigate the exact nature of the pigments within the bacteria. We see a similar pattern with the Gram status of cave bacteria as compared to surface bacteria. As with pigmentation, the thicker cells walls of the Gram-positive bacteria are better able to protect the bacteria from UVR damage, resulting in an advantage for Gram-positive surface bacteria. Additionally, the anti-desiccation role of Gram-positive walls also would be less advantageous in the high humidity environment of caves. Thicker cell walls probably require more energy to create, and thus, in the limited resources environment of the cave, may no longer have an adaptive advantage.

In conclusion, our study shows that cave microorganisms do show a decreased ability to survive damage from UV irradiation when presumably using a light-independent repair system. They also appear to have modified cellular traits, such as reduced pigmentation, no longer essential to protect their DNA from the damaging effects of UVR. We believe that these results show evidence that a cave microbial phenotype in cave bacteria may be distinguishable. However, this study is only the start of establishing the existence of a bacterial cave phenotype. Investigating the presence of the repair mechanisms, in-depth analysis of the pigments and further molecular and culture testing are clearly needed.

\section{ACKNOWLEDGEMENTS}

The authors would like to thank Drs. Hazel Barton and Kathy Lavoie for their usefulconversations and suggestions to improve experimental design, James Cleverly for his help with NIH Imager software, Casey Gilman for her management of the bacterial isolates, Amaka Nwagbologu for assistance in media preparation, Kenneth Ingham and Takasumi Sasaki for their photographic assistance, Amanda Trent, Ariel Boston, and Vicki Peck for their preliminary research and John Craig for his help with everything from experimental design to double checking calculations. We acknowledge technical support from the University of New Mexico's Molecular Biology Facility which is supported by NIH Grant Number 1P20RR18754 from the Institute Development Award (IDeA) Program of the National Center for Research Resources. Finally, 
we will like to thank the Cave Resources Office at Carlsbad Caverns National Park for their assistance and permits in sample collection and Tom Bemis for his data on lighting characteristics in Carlsbad Cavern.

This material is based upon work supported by the National Science Foundation under grants No. MBC0132097, No. DGE-9972810, and No.DGE-0538396 and funding from Kenneth Ingham Consulting Inc.

\section{REFERENCES}

Altschul S.F., Madden T.L., Schäffer A.A., Zhang J., Zhang Z., Miller W. \& Lipman D.J., 1997 - Gapped BLAST and PSI-BLAST: a new generation of protein database search program. Nucleic Acid Research, 25: 3389-3402.

Arrage A.A., Phelps T.J., Benoit R.E. \& White D.C., 1993a - Survival of subsurface

microorganisms exposed to UV radiation and hydrogen peroxide. Applied and Environmental Microbiology, 59: 3545-3550.

Arrage A.A., Phelps T.J. Benoit R.E., Palumbo A.V. \& White D.C., 1993b - Bacterial sensitivity to UV light as a model for ionizing radiation resistance. Journal of Microbiological Methods, 18: 127-136.

Ashleford K.E., Chuzhanova N.A., Fry J.C., Jones A.J. \& Weightman A.J., 2006 - New screening software shows that most recent large $16 \mathrm{~S}$ rRNA gene clone libraries contain chimeras. Applied and Environmental Microbiology, 72: 5734-5741.

Barton H.A., Taylor, N.M., Kreate A.P., Springer A.C., Oehrle S.A. \& Bertog J.L., 2007- The impact of host rock geochemistry on bacterial community structure in oligotrophic cave environments. International Journal of Speleology, 36: 93-104.

Booth M.G., Jeffrey W.H. \& Miller R.V., 2001 - RecA expression in response to solar UVR in the marine bacterium Vibrio natreiegens. Microbial Ecology, 42: 531-539.

Carell T., Burgdorf L.T., Kundu L.M. \& Cichon M., 2001 - The mechanism of action of DNA photolyases. Current Opinion in Chemical Biology, 5: 491-498.

Cockell C.S., 1998 - Biological effects of high ultraviolet radiation on early Earth-A theoretical evaluation. Journal of Theoretical Biology, 193: 717-729.

Culver D.C., 1982 - Cave Life: Evolution and Ecology. Cambridge, MA: Harvard University Press: 189 p.

Dor I. \& Dor Y., 1999 - Cyanobacterial flora of the Soreq stalactite Cave (Israel) and way of its control. Algological Studies, 94: 115-120.

Dworkin M. \& Stanley F., 2006 - Light as an Extreme Environment. In Dworkin M., and Stanley F. (Eds.), The Prokaryotes: a Handbook on the Biology of Bacteria. New York: Springer: (electronic resource).

Gascon J., Oubina A., Perez-Lezuan A. \& Urmeneta J., 1995 - Sensitivity of selected bacterial species to UV radiation. Current Microbiology, 30: 177-182.

Gradzinski M., Szulc J. \& Smyk B., 1997- Microbial agents of moonmilk calcification. Proceedings $12^{\text {th }}$ International Congress of Speleology, Vol 1, Swiss Speleological Society, La Chaux-de Fonds, Jeannin, P.Y., ed.: pp. 275-278.
Groth I., Schumann P., Schütze B., Augsten K. \& Stackerbrandt E., 2002 - Knoellia sinensis gen. nov., sp. nov. and Knoellia subterranean sp. nov., two novel actinobacteria isolated from a cave. International Journal of Systematic and Evolutionary Microbiology, 52: 77-84.

Hill C.A. \& Forti P., 1997- Cave Minerals of the World ( $2^{\text {nd }}$ edition). Huntsville: National Speleological Society: $463 \mathrm{p}$.

Jagger J. 1983 - Physiological effects of nearultraviolet radiation on bacteria. Photochemical and Photobiological Reviews, 7: 1-75.

Jagger J, 1985. Solar-UV Actions on Living Cells. New York: Praeger Publishers, 202 p.

Kokjohn T. A. \& Miller R.V., 1985 - Molecular cloning and characterization of the recA gene of Pseudomonas aeruginosa. Journal of Bacteriology, 163: 568572 .

Langecker T.C., 2000 - The effects of continuous darkness on cave ecology and cavernicolus evolution. In: Wilkins H., Culver D.C., and W. F. Humphreys W.F. (Eds.), Subterranean Ecosystems. New York: Elsevier: pp. 135-158.

Lammert J., 2007 -Techniques in Microbiology: a Student Handbook. San Francisco, CA: Pearson Education, Inc. Press: 226 p.

Lewis N.F., Madhavesh D.A. \& Kumta U.S., 1973 - Role of carotenoid pigments in radio-resistant micrococci. Canadian Journal of Microbiology, 20: 455-459.

Mathews M.M. \& Sistrom WR., 1959 - Functions of carotenoid pigments in non-photosynthetic bacteria. Nature, 184: 1892-1893.

Miller R.V., Jeffrey W., Mitchell D. \& Elasri M., 1999 - Bacterial response to solar ultraviolet light. ASM News, 65: 535-541.

Miller R.V., 2000 - recA: The gene and its protein product. In Luria S. (Ed.) Encylopedia of Microbiology, $2^{\text {nd }}$ Edition, Vol.4. San Diego, CA: Academic Press: pp. 43-54.

Nasim A. \& James A.P., 1978- Life under conditions of high irradiation. In Kushner D.J. (Ed.), Microbial Life in Extreme Environments. New York: Academic Press: pp. 409-439.

Northup D.E., Connolly C.A., Trent A., Boston P.J., Peck V.M. \& Natvig D.O., 2008 - On the nature of bacterial communities in Four Windows Cave, El Malpais National Monument, New Mexico, USA. AMCS Bulletin, 19: 119-125.

Northup D.E., Dahm C.N., Melim L.A., Spilde M.N. Crossey L.J., Lavoie K.H., Mallory L., Boston P.J., Cunningham K.I. \& Barns S.M., 2000 -Evidence for geomicrobiological interactions in Guadalupe (NM) Caves. Journal of Cave and Karst Studies, 62:8090.

Northup D.E., Lavoie L.H. \& Studier E.H., 1993 Bioenergetics of Ceuthophilus camel crickets from Carlsbad Caverns National Park. Comparative Biochemistry and Physiology, 106A: 525-529.

Rothschild L.J. \& Giver L., 2003 - Photosynthesis below the surface in a cryptic microbial mat. International Journal of Astrobiology 1: 295-304. 
Simonson C.S., Kokjohn T.A. \& Miller R.V., 1990 - Inducible UV repair potential of Pseudomonas aeruginosa PAO. Journal of General Microbiology, 136: $1241-1249$.

Singer C.E. \& Ames B.N., 1970 - Sunlight ultraviolet and bacterial DNA base ratios. Science, 170: 822-826.
Walter M.R., 1983-Archaen stromatolites: Evidence of the Earth's earliest benthos. In Schopf W.J. (Ed.) Earth's Earliest Biosphere. Princeton: Princeton University Press: pp.187-213.

Yasui A. \& McCready S.J. 1998. Alternative repair pathways for UV-induced DNA damage. Bioassays, 20: 291-297. 